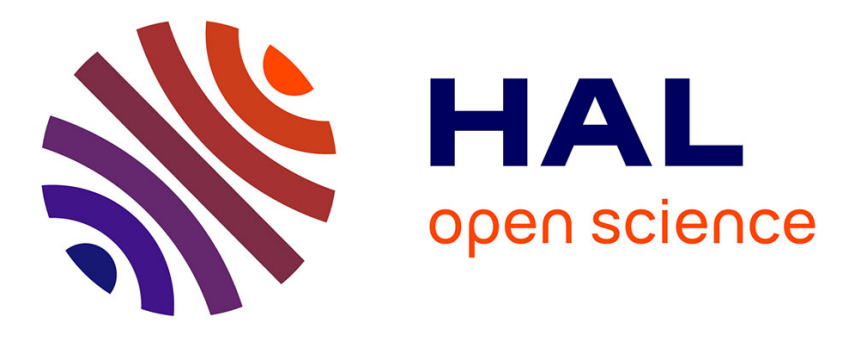

\title{
Nonlinear fault damage zone scaling revealed through analog modeling
}

Sylvain Mayolle, Roger Soliva, Stéphane Dominguez, Christopher Wibberley, Yannick Caniven

\section{To cite this version:}

Sylvain Mayolle, Roger Soliva, Stéphane Dominguez, Christopher Wibberley, Yannick Caniven. Nonlinear fault damage zone scaling revealed through analog modeling. Geology, 2021, 49 (8), pp.968-972. 10.1130/g48760.1. hal-03331799

\section{HAL Id: hal-03331799 \\ https://hal.science/hal-03331799}

Submitted on 2 Sep 2021

HAL is a multi-disciplinary open access archive for the deposit and dissemination of scientific research documents, whether they are published or not. The documents may come from teaching and research institutions in France or abroad, or from public or private research centers.
L'archive ouverte pluridisciplinaire HAL, est destinée au dépôt et à la diffusion de documents scientifiques de niveau recherche, publiés ou non, émanant des établissements d'enseignement et de recherche français ou étrangers, des laboratoires publics ou privés. 


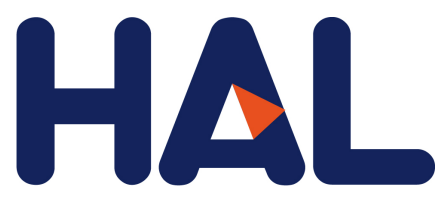

archives-ouvertes

\section{Nonlinear fault damage zone scaling revealed through analog modeling}

Sylvain Mayolle, Roger Soliva, Stéphane Dominguez, Christopher Wibberley, Yannick Caniven

\section{To cite this version:}

Sylvain Mayolle, Roger Soliva, Stéphane Dominguez, Christopher Wibberley, Yannick Caniven. Nonlinear fault damage zone scaling revealed through analog modeling. Geology, Geological Society of America, 2021, 10.1130/g48760.1 . hal-03331799

\section{HAL Id: hal-03331799 \\ https://hal.archives-ouvertes.fr/hal-03331799}

Submitted on 2 Sep 2021

HAL is a multi-disciplinary open access archive for the deposit and dissemination of scientific research documents, whether they are published or not. The documents may come from teaching and research institutions in France or abroad, or from public or private research centers.
L'archive ouverte pluridisciplinaire HAL, est destinée au dépôt et à la diffusion de documents scientifiques de niveau recherche, publiés ou non, émanant des établissements d'enseignement et de recherche français ou étrangers, des laboratoires publics ou privés. 


\title{
Nonlinear fault damage zone scaling revealed through analog modeling
}

\author{
Sylvain Mayolle ${ }^{*}$, Roger Soliva ${ }^{1}$, Stéphane Dominguez ${ }^{1}$, Christopher Wibberley ${ }^{2}$ and Yannick Caniven ${ }^{3}$ \\ ${ }^{1}$ Géosciences Montpellier, Université de Montpellier, CNRS, Université des Antilles, 34095 Montpellier, France \\ ${ }^{2}$ Centre Scientifique et Technique Jean Féger (CSTJF), TOTAL EP, Avenue Larribau, 64018 Pau, France \\ ${ }^{3}$ Earth, Environmental and Planetary Sciences, Rice University, Houston, Texas 77005, USA
}

\begin{abstract}
Fault damage zones strongly influence fluid flow and seismogenic behavior of faults and are thought to scale linearly with fault displacement until reaching a threshold thickness. Using analog modeling with different frictional layer thicknesses, we investigate damage zone dynamic evolution during normal fault growth. We show that experimental damage zone growth with displacement is not linear but progressively tends toward a threshold thickness, being larger in the thicker models. This threshold thickness increases significantly at fault segment relay zones. As the thickness threshold is approached, the failure mode progressively transitions from dilational shear to isochoric shear. This process affects the whole layer thickness and develops as a consequence of fault segment linkage as inferred in nature when the fault matures. These findings suggest that fault damage zone widths are limited both by different scales of mechanical unit thickness and the evolution of failure modes, ultimately controlled in nature by lithology and deformation conditions.
\end{abstract}

\section{INTRODUCTION}

Fracture damage zones around faults control many aspects of fluid flow properties and the seismogenic behavior of faults. Their width is a key parameter controlling the hydraulic behavior of the fault, energy dissipation during earthquake ruptures, and stress distribution (e.g., Faulkner et al., 2010; Perrin et al., 2016). Several studies over the past decade have evidenced a linear scaling between fault displacement $(D)$ and damage zone thickness $(T)$ up to a scale limit of a few hundred meters (Micarelli et al., 2006; Savage and Brodsky, 2011; Mitchell and Faulkner, 2012; Johri et al., 2014; Solum and Huisman, 2017; Mayolle et al., 2019; Torabi et al., 2020), defining a threshold in the scaling. Although discussed in terms of seismogenic depth for earthquake-related damage (Ampuero and Mao, 2017), the existence of such a threshold for faults is not yet supported by a physical explanation. In this study, we developed a rheologically consistent and scaled analog model of

*E-mail: sylvain.mayolle@umontpellier.fr
Earth's brittle crust to experimentally investigate the existence of such a threshold in $D-T$ scaling and to identify the main controlling parameters. With these aims, we measured the strain field evolution, $D-T$ scaling, and volumetric strain using high-resolution image correlation for models of different layer thickness.

\section{MODEL SETUP}

We present the two most illustrative tests from a series of 16 experiments designed to study reproducibility, the role of material composition, and the relevant boundary conditions (see the Supplemental Material ${ }^{1}$ ). These two experiments were performed in a sandbox device $500 \mathrm{~mm}$ long, $300 \mathrm{~mm}$ high, and $100 \mathrm{~mm}$ wide, equipped with two lubricated low-friction glass walls and containing two layers of composed of $97.5 \%$ dry sand of $150 \mu$ m mean grain size and $2.5 \%$ pumice powder of similar packing to ensure reproducibility. The static friction angle and the cohesion were $38^{\circ} \pm 1^{\circ}$ and $185 \pm 20 \mathrm{~Pa}$, respectively, and dilation angle granular materials (Fig. 1). The upper layer was decreased with increasing plastic strain. These physical properties are analogous to those of upper-crustal rocks, and cohesion was scaled to satisfy a model-to-nature scaling of $1 \mathrm{~cm}$ equivalent to $0.5-1 \mathrm{~km}$ in nature (e.g., Schellart, 2000; Arzúa and Alejano, 2013; Reber et al., 2020). Such materials consistently reproduce the main geometries of faults and their segmentation, interaction, displacement profiles, and gradients, but also displacement-length and size distribution scaling laws (e.g., Bellahsen and Daniel, 2005; Schlagenhauf et al., 2008). The lower layer was a mixture of $98 \%$ dry sand of $150 \mu \mathrm{m}$ mean grain size and $2 \%$ polydimethylsiloxane silicone (kinetic sand), inducing a visco-plastic mechanical behavior simulating that of the lower crust or ductile shales. These two layers lay on a pre-compressed elastic polyurethane foam which, once relaxed by movement of a lateral backstop, induces distributed extensional strain in the layers above (Fig. 1). The extension velocity $(30 \mathrm{~mm} / \mathrm{h})$ was regulated by a computer-controlled motor and allowed a total extension of $100 \mathrm{~mm}(20 \%)$. We performed two sets of experiments with different frictional upper-layer thicknesses: $50 \mathrm{~mm}$ and $200 \mathrm{~mm}$ (i.e., $\sim 4 \mathrm{~km}$ and $\sim 15 \mathrm{~km}$ thickness in nature). The kinetic sand thickness of the lower layer was $20 \mathrm{~mm}$ for the thinner model and $40 \mathrm{~mm}$ for the thicker model. All the experiments were monitored through the lateral glass wall using a Sony $\alpha 7 R$ II camera taking one photo every $30 \mathrm{~s}$ with a resolution of 1 pixel $=54 \mu \mathrm{m}$.

The acquired images were processed to analyze the displacement field using a subpixel spectral correlation algorithm from Van Puymbroeck et al. (2000) (Fig. 1) and were also used to provide movies of the strain field

${ }^{1}$ Supplemental Material. (1) Movie and description of displacement gradient field evolution; (2) movie of strain fields evolution; (3) cummulative displacement field; (4) displacement gradient profiles through faults; (5) volumetric strain profiles through faults; (6) mechanical properties of the frictional layer; (7) images and parametric data of all the models; (8) a graph of all the measured $D-T$ data; and additional information on the method and scaling to nature. Please visit https://doi .org/10.1130/XXXXX to access the supplemental material, and contact editing@ geosociety.org with any questions. 


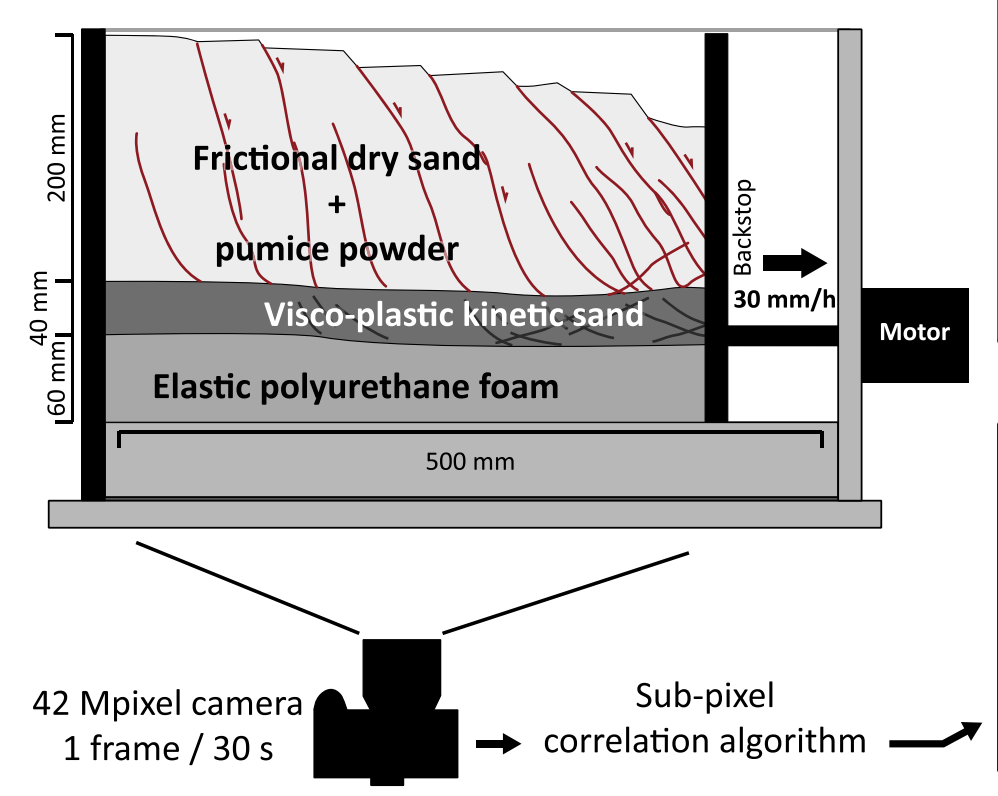

Figure 1. Experimental setup. At the base of the model, elastic foam is uncompacted by a computerized motor, imposing extension in the upper visco-plastic kinetic sand and frictional layer. The vertical displacement and vertical strain field derived from sub-pixel image correlation are shown on the right-hand side. (see the Supplemental Material). The cumulative displacement field ( $U$; i.e., the sum of displacement fields derived from each image correlation) and cumulative net shear displacement along the faults $(D)$ were calculated using the horizontal and vertical displacement fields. Cumulative damage zone thickness $(T)$ was determined using the distribution of displacement gradient across the fault $(d U / d x$; i.e., grdgradient function in Generic Mapping Tools software (GMT, https://www.genericmapping-tools.org/), the amplitude of the gradient) (Fig. 2A). This displacement gradient field is the most relevant field attribute for measuring fault thickness because it accounts for both the absolute displacement (any direction) and displacement modes (shear, dilation, and compaction). For each model, strain evolution is analyzed along six profiles normal to two selected fault planes. The Gaussian distribution of the displacement gradient along these profiles is compared to background deformation outside the Gaussian curve to define damage zone thickness (Fig. 2B). In an area devoid of faults, an upper limit of the background displacement gradient is used at each stage of image correlation, defined as $3 \sigma$ of the modal value of the background displacement gradient (horizontal dashed line in Fig. 2B). The distance between the two points where the Gaussian distribution reaches this upper background value defines $T$, the cumulative damage zone thickness (Fig. 2B, stage 2). Thus, $T$ is measured in relation to background deformation as is commonly done along scanlines from field data (e.g., Beach et al., 1999; Choi et al., 2016; Ostermeijer et al., 2020). Areas perturbed by boundary conditions are excluded from measurements (see the Supplemental Material).
We also measure the incremental volumetric strain $\left(d \varepsilon_{v}\right)$ along the faults to investigate its evolution in relation to the scaling behavior. To quantify its evolution relative to the incremental shear displacement during fault growth, we also calculate its derivative in the form, $d \varepsilon_{\mathrm{v}} / d D$.

\section{RESULTS \\ Fault Geometry}

Experimental faults initiate as shear zones dipping $\sim 60^{\circ}$ toward the moving backstop, and cumulate, at the end of the experiment, a net shear displacement of as much as $4 \mathrm{~mm}$ for the model with $50 \mathrm{~mm}$ upper-layer thickness $(8 \%)$ and as much as $7 \mathrm{~mm}$ for the model with $200 \mathrm{~mm}$ upper-layer thickness (3.5\%) (Fig. 2A). They die out at depth by diffuse deformation into the visco-plastic kinetic sand layer. In the $200 \mathrm{~mm}$ model, individual dilational-shear segments are observed in the very early stages of shear zone development, linking up as the faults grow, leading to irregular fault surface geometries (Fig. 2C, stages 1 and 2). During the experiment, all the faults grow wider as displacement increases (Figs. 2A and 2B, stages 1 and 2). With increasing displacement, the fault deformation concentrates on narrow zones, which become straight and continuous through the sand layer (Fig. 2C, transition from stage 2 to stage 3 ). This strain localization is also shown by the change in shape of the Gaussian curve of displacement gradient profiles across the faults, which increases its amplitude faster than its wavelength (Fig. 2B).

The incremental volumetric strain field reveals that in the frictional layer, the first stages of fault thickening occur under a dominant dilational-shear mode (Fig. 2C, stage 1). The deriva- tive of this incremental volumetric strain with respect to the net shear displacement $\left(d \varepsilon_{\mathrm{v}} / d D\right)$ increases but never exceeds 0.15 . Fault widening continues to evolve by a combination of dilational-shear and compactional-shear modes (Fig. 2C, stage 2). Dilational shear occurs in a wide and diffuse volume of the fault, especially at the steeper parts of the fault plane. Compactional shear initiates in limited regions of the fault, especially at contractional bends along the irregular fault surface (Fig. 2C, stage 2). Following this stage, a very thin zone of compactionalshear deformation, visible in the incremental volumetric strain field, develops over a larger extent along the fault and can reach a value of -0.14 (Fig. 2C, stage 3). Although its geometry is variable from one fault to another, this very thin compactional-shear zone is surrounded by synchronous dilational-shear deformation, spreading away from the fault at specific locations such as zones of segment linkage (Fig. 2B, stage 3 ). The cumulative effect of these two synchronous deformation modes results in net $d \varepsilon_{\mathrm{v}} / d D$ values ranging from -0.05 to 0.05 over the fault width, commonly close to 0 because incremental compaction and dilation are similar in magnitude.

\section{D-T Scaling}

Figure $3 \mathrm{~A}$ shows a plot of $D$ versus $T$ measured in the two sets of experiments along profiles both across fault segments with simple geometries (i.e., no intersections, no branching) and across more complex zones such as fault branches and relay zones. The $d \varepsilon_{\mathrm{v}} / d D$ ratio is indicated for each stage measured. This diagram reveals that damage zone thickness grows nonlinearly with increasing fault displacement (Figs. 3A and 3B). The first stage of 

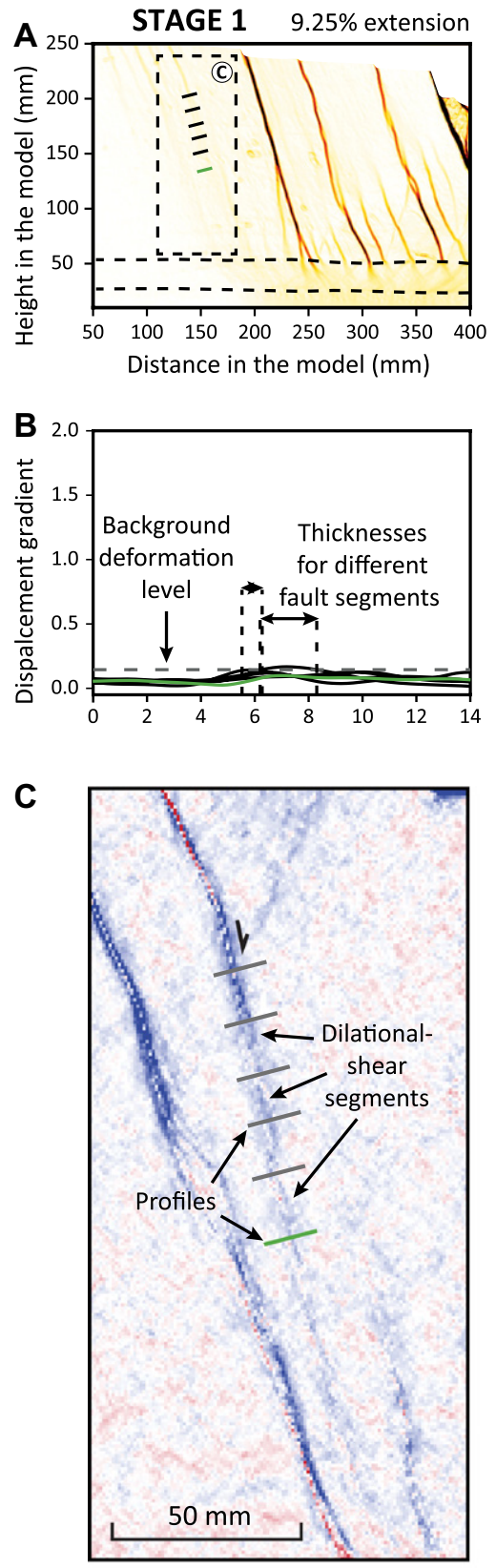
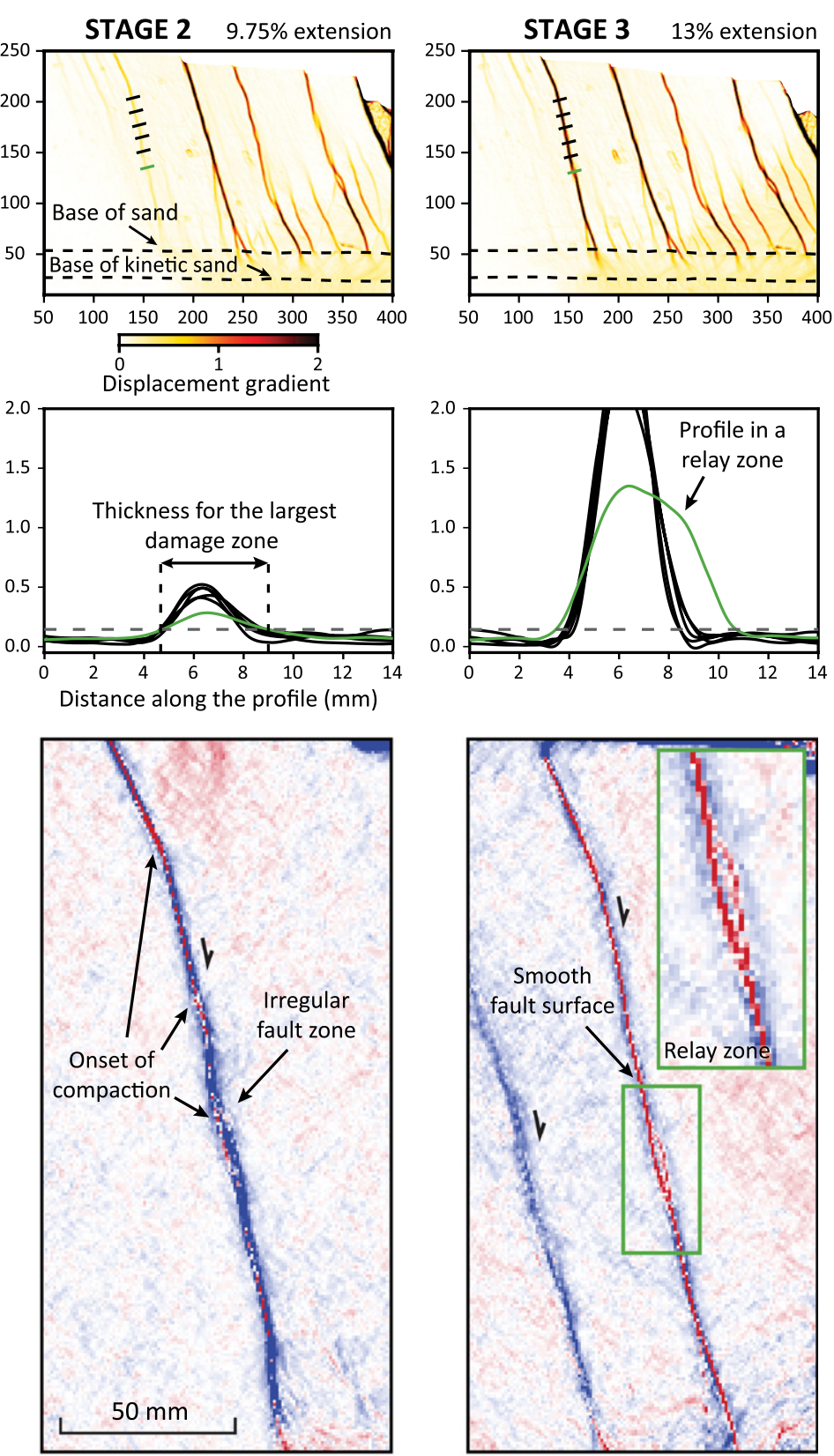

Figure 2. Example of fault growth in the experiment with a 200-mm-thick upper layer at three different stages. (A) Displacement gradient field. Damage zone thickness is measured along five profiles crossing simple fault geometry (in black) and one profile in the relay zone (green). (B) Displacement gradient distribution along profiles shown in A. Gray dashed line is upper limit of background deformation. (C) Incremental volumetric strain in the black dashed rectangle shown in A. Pixels represent image correlation resolution. Strain field movies are presented in the Supplemental Material (see footnote 1).

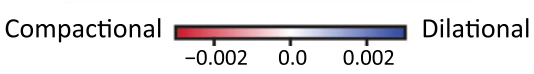

Incremental volumetric strain

fault growth shows a nonlinear rapid increase of fault thickness with fault displacement, in which the fault develops in a hybrid dilationalshear failure mode (blue symbols in Figs. 3A and $3 \mathrm{~B}$ ). In both models, this nonlinear increase occurs up to a value of $D=\sim 0.8 \mathrm{~mm}$, where the $d T / d D$ ratio stabilizes around a very low mean value of 0.18 (with $2 \sigma=0.6$ ), reflecting very little increase of damage zone thickness with displacement (thickness threshold). This stabilization of the $d T / d D$ ratio occurs nearly synchronously with a change of failure mode from dominant dilational-shear behavior (dark blue symbols) to isochoric shear (white, light blue, or pink symbols). The $d \varepsilon_{\mathrm{v}} / d D$ value then remains nearly stable until the end. Note that this behavior is observed in each of the different model layer thicknesses, but the damage zone thickness at which the fault stabilizes is $\sim 20 \%$ higher for the thicker model in cases of simple fault segments. In the thicker model, $T$ values measured at relay zones are $\sim 30 \%$ larger than along segments. At relay zones, the main curvature of the $D-T$ data trend is also smoother (Figs. 2A and 2B, green profile; Fig. 3A), showing a later and more gradual transition of failure mode from dilational shear to isochoric shear. Finally, due to this thickness threshold, $D$ becomes larger than $T$ in the later stages of the models (see the Supplemental Material), consistent with natural faults when D> $100 \mathrm{~m}$.

\section{DISCUSSION}

Our experiments show that (1) nonlinear $D-T$ scaling occurs toward a plateau at a threshold value of damage zone thickness dependent on layer thickness, (2) a change of dominant failure mode occurs when the $d T / d D$ ratio stabilizes toward a value close to zero, and (3) the threshold damage zone thickness increases significantly at fault segment relay zones, for which the width is large in the thicker model. This latter effect promotes a delay in the stabilization of the $d T / d D$ ratio and allows a more progressive transition in failure mode.

A hybrid dilational-shear mode is prominent in the first stage of fault growth during fault segment initiation and propagation. This 

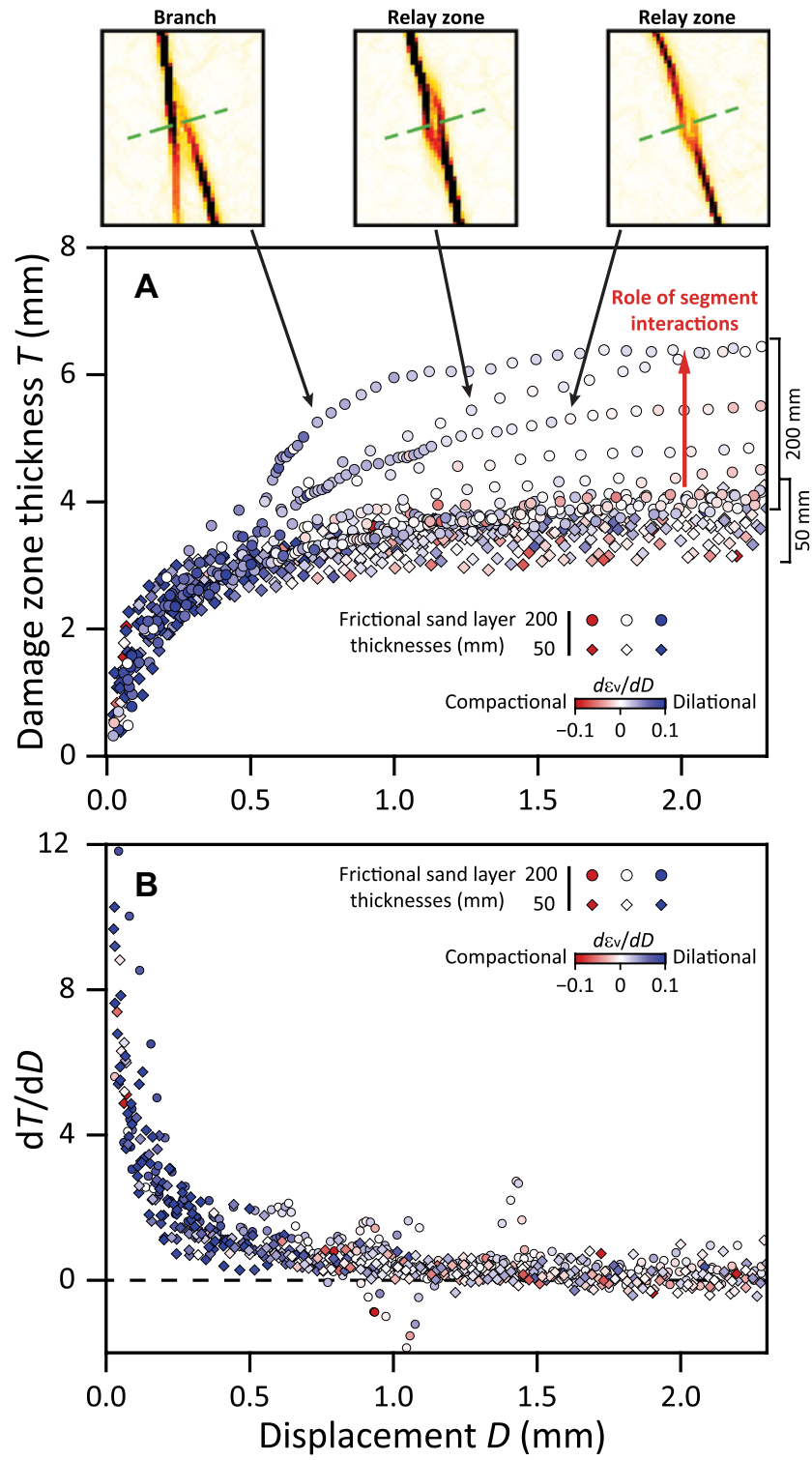

Figure 3. (A) Displacement $(D)$-damage zone thickness $(T)$ data from our experiments for two different frictional layer thicknesses $(200 \mathrm{~mm}$ and $50 \mathrm{~mm}$ ) measured along 24 profiles crossing four selected faults. Three examples of segment interactions are shown with corresponding displacement gradient fields. Green dashed lines show positions of measurement profiles. (B) $d T / d D$ versus displacement. Symbol color scale is $d \varepsilon_{v} / d D$ in both graphs, where $d \varepsilon_{\mathrm{v}}$ is incremental volumetric strain.

dilation is preserved later in extensional relay zones and around the fault as shear localization occurs (Fig. 2C). Hybrid dilational-shear failure modes are recorded in low-cohesion granular materials as shear-enhanced dilation due to grain disaggregation and rotation during shear (e.g., Rowe, 1962; Antonellini et al., 1994). Although the granular material does not produce transgranular fractures, it reproduces the main features of fault network geometry such as tip propagation, segmentation, linkage at relays, and fault bends, all of which contribute to generating the deformation volume around the fault as observed in nature irrespective of the deformation micro-mechanisms (e.g., Childs et al., 2009; Wibberley et al., 2008; Figure 2C; also see the Supplemental Material). This is because the mechanical behavior is consistent with stiffer rocks, and the grain size in our models is much lower than the fault thickness at saturation (by one to two orders of magnitude). For the same reason, initial grain-scale heterogeneity prob-

clearly cuts the entire thickness of the frictiona layer and compactional-shear initiates on favorably oriented parts of the irregularities related to the earlier segmentation (Mayolle et al. 2019). In a latter stage, compaction develops through the entire fault, probably due to the low strength of the dilated zones (Wong and Baud, 1999; Rutter and Glover, 2012), which helps suppress further thickening. This process reflects strain localization and failure of the frictional layer and progressively inhibits dilational shear to promote isochoric shear within a fault of constant thickness.

\section{COMPARISON TO NATURE AND CONCLUSION}

The models show first-order similarities with natural data such as fault dip angles, conjugate geometries, segmentation, and $D-T$ trend. Although precise scaling cannot be achieved, the ratio of layer thickness to mean threshold thickness found in the thick model $(200 \mathrm{~mm} /$ $4.5 \mathrm{~mm}$ ) is close to the ratio expected for natural faults in the seismogenic crust $(15 \mathrm{~km} /$ $0.3 \mathrm{~km}$; Savage and Brodsky, 2011; Solum and Huisman, 2017). Also, the observed volumetric strain can be considered, to a certain extent, analogous to fracture dilation and compaction occurring within faults (mode I fractures, dilatant breccias versus cataclasites, gouge smearing, S-C structures, cleavage, and pressure-solution seams; e.g., Billi et al., 2003; Gratier et al., 2011; Ishii, 2016; Vrolijk et al., 2016). In addition, it is well known that mode I fractures generally develop early in the growth history of a fault in natural rocks (e.g., Petit et al., 1999; Crider and Peacock, 2004). Larger faults generally show a combination of preferentially dilational-shear damage zones and compactional-shear core zones (e.g., Wibberley and Shimamoto, 2003; Faulkner et al., 2010; Holdsworth et al., 2011), with an average spatial arrangement consistent with the volumetric strain distribution presented in this study.

Finally, as the overall mechanical controls on the failure-mode transition govern the threshold of damage zone growth, this threshold is likely to be specific to the geological context of any one fault, probably accounting for the large scatter observed in the natural data (Savage and Brodsky, 2011). However, this study suggests that mechanical layering is probably one of the most important parameters governing this threshold and scattering in nature, and such layering exists at several scales, with the ultimate scale limit of layer thickness controlling fault damage zone width being the thickness of the brittle upper crust. Other parameters like lithology, tectonic setting (e.g., Balsamo et al., 2019), and the physico-chemical behavior of fluids in the fault are probably also important for scattering. For this reason, the specific context of any one fault must be taken into account when comparing different data sets for establishing overall scaling laws.

\section{ACKNOWLEDGMENTS}

TOTAL SA and Geoscience Montpellier provided financial support of this research developed during the DAMAGE research program hosted at the University of Montpellier. We thank C. Romano for technical assistance. We thank A. Braathen, F. Balsamo, R Schultz, and anonymous reviewers for their helpful reviews. 


\section{REFERENCES CITED}

Ampuero, J.P., and Mao, X., 2017, Upper limit on damage zone thickness controlled by seismogenic depth, in Thomas, M.Y., et al., eds., Fault Zone Dynamic Processes: Evolution of Fault Properties During Seismic Rupture: American Geophysical Union Geophysical Monograph 227, p. 243-253, https://doi.org/10.1002/9781119156895.ch13.

Antonellini, M.A., Aydin, A., and Pollard, D.D., 1994 Microstructure of deformation bands in porous sandstones at Arches National Park, Utah: Journal of Structural Geology, v. 16, p. 941-959, https:// doi.org/10.1016/0191-8141(94)90077-9.

Arzúa, J., and Alejano, L.R., 2013, Dilation in granite during servo-controlled triaxial strength tests: International Journal of Rock Mechanics and Mining Sciences, v. 61, p. 43-56, https://doi .org/10.1016/j.ijrmms.2013.02.007

Balsamo, F., Clemenzi, L., Storti, F., Solum, J., and Taberner, C., 2019, Tectonic control on vein attributes and deformation intensity in fault damage zones affecting Natih platform carbonates, Jabal Qusaybah, North Oman: Journal of Structural Geology, v. 122, p. 38-57, https://doi.org/10.1016/ j.jsg.2019.02.009.

Beach, A., Welbon, A.I., Brockbank, P.J., and McCallum, J.E., 1999, Reservoir damage around faults; Outcrop examples from the Suez Rift: Petroleum Geoscience, v. 5, p. 109-116, https:// doi.org/10.1144/petgeo.5.2.109.

Bellahsen, N., and Daniel, J.M., 2005, Fault reactivation control on normal fault growth: an experimental study: Journal of Structural Geology, v. 27, p. 769-780, https://doi.org/10.1016/ j.jsg.2004.12.003.

Billi, A., Salvini, F., and Storti, F., 2003, The damage zone-fault core transition in carbonate rocks: Implications for fault growth, structure and permeability: Journal of Structural Geology, v. 25, p. 1779-1794, https://doi.org/10.1016/ S0191-8141(03)00037-3.

Childs, C., Manzocchi, T., Walsh, J.J., Bonson, C.G., Nicol, A., and Schöpfer, M.P.J., 2009, A geometric model of fault zone and fault rock thickness variations: Journal of Structural Geology, v. 31, p. 117-127, https://doi.org/10.1016/ j.jsg.2008.08.009.

Choi, J.-H., Edwards, P., Ko, K., and Kim, Y.-S., 2016, Definition and classification of fault damage zones: A review and a new methodological approach: Earth-Science Reviews, v. 152, p. 70-87, https://doi.org/10.1016/j.earscirev.2015.11.006.

Crider, J.G., and Peacock, D.C.P., 2004, Initiation of brittle faults in the upper crust: A review of field observations: Journal of Structural Geology, v. 26, p. 691-707, https://doi.org/10.1016/ j.jsg.2003.07.007.

Faulkner, D.R., Jackson, C.A.L., Lunn, R.J., Schlische, R.W., Shipton, Z.K., Wibberley, C.A.J., and Withjack, M.O., 2010, A review of recent developments concerning the structure, mechanics and fluid flow properties of fault zones: Journal of Structural Geology, v. 32, p. 1557-1575, https:// doi.org/10.1016/j.jsg.2010.06.009.

Gratier, J.-P., Richard, J., Renard, F., Mittempergher, S., Doan, M.-L., Di Toro, G., Hadizadeh, J., and Boullier, A.-M., 2011, Aseismic sliding of active faults by pressure solution creep: Evidence from the San Andreas Fault Observatory at Depth: Geology, v. 39, p. 1131-1134, https:// doi.org/10.1130/G32073.1.

Holdsworth, R.E., van Diggelen, E.W.E., Spiers, C.J. de Bresser, J.H.P., Walker, R.J., and Bowen, L., 2011, Fault rocks from the SAFOD core samples: Implications for weakening at shallow depths along the San Andreas Fault, California: Journal of Structural Geology, v. 33, p. 132-144, https:// doi.org/10.1016/j.jsg.2010.11.010.

Ishii, E., 2016, Far-field stress dependency of the failure mode of damage-zone fractures in fault zones: Results from laboratory tests and field observations of siliceous mudstone: Journal of Geophysical Research: Solid Earth, v. 121, p. 70-91, https://doi.org/10.1002/2015JB012238.

Johri, M., Zoback, M.D., and Hennings, P., 2014, A scaling law to characterize fault-damage zones at reservoir depths: American Association of Petroleum Geologists Bulletin, v. 98, p. 2057-2079, https://doi.org/10.1306/05061413173.

Mayolle, S., Soliva, R., Caniven, Y., Wibberley, C., Ballas, G., Milesi, G., and Dominguez, S., 2019, Scaling of fault damage zones in carbonate rocks: Journal of Structural Geology, v. 124, p. 35-50, https://doi.org/10.1016/j.jsg.2019.03.007.

Micarelli, L., Benedicto, A., and Wibberley, C.A.J., 2006, Structural evolution and permeability of normal fault zones in highly porous carbonate rocks: Journal of Structural Geology, v. 28, p. 1214-1227, https://doi.org/10.1016/ j.jsg.2006.03.036.

Mitchell, T.M., and Faulkner, D.R., 2012, Towards quantifying the matrix permeability of fault damage zones in low porosity rocks: Earth and Planetary Science Letters, v. 339-340, p. 24-31, https://doi.org/10.1016/j.eps1.2012.05.014.

Ostermeijer, G.A., Mitchell, T.M., Aben, F.M., Dorsey, M.T., Browning, J., Rockwell, T.K., Fletcher, J.M., and Ostermeijer, F., 2020, Damage zone heterogeneity on seismogenic faults in crystalline rock: A field study of the Borrego Fault, Baja California: Journal of Structural Geology, v. 137, 104016, https://doi.org/10.1016/ j.jsg.2020.104016.

Perrin, C., Manighetti, I., Ampuero, J.-P., Cappa, F., and Gaudemer, Y., 2016, Location of largest earthquake slip and fast rupture controlled by along-strike change in fault structural maturity due to fault growth: Journal of Geophysical Research: Solid Earth, v. 121, p. 3666-3685, https:// doi.org/10.1002/2015JB012671.

Petit, J.-P., Wibberley, C.A.J., and Ruiz, G., 1999, 'Crack-seal', slip: A new fault valve mechanism?: Journal of Structural Geology, v. 21, p. 1199-1207, https://doi.org/10.1016/ S0191-8141(99)00038-3.

Reber, J.E., Cooke, M.L., and Dooley, T.P., 2020, What model material to use? A review on rock analogs for structural geology and tectonics: Earth-Science Reviews, v. 202, 103107, https:// doi.org/10.1016/j.earscirev.2020.103107.

Rowe, P.W., 1962, The stress-dilatancy relation for static equilibrium of an assembly of particles in contact: Proceedings of the Royal Society of London: Series A, Mathematical and Physical Sciences, v. 269, p. 500-527, https://doi.org/10.1098/ rspa.1962.0193.

Rutter, E.H., and Glover, C.T., 2012, The deformation of porous sandstones: Are Byerlee friction and the critical state line equivalent?: Journal of Structural Geology, v. 44, p. 129-140, https://doi .org/10.1016/j.jsg.2012.08.014.

Savage, H.M., and Brodsky, E.E., 2011, Collateral damage: Evolution with displacement of fracture distribution and secondary fault strands in fault damage zones: Journal of Geophysical Research, v. 116, B03405, https://doi .org/10.1029/2010JB007665.

Schellart, W.P., 2000, Shear test results for cohesion and friction coefficients for different granular materials: Scaling implications for their usage in analogue modelling: Tectonophysics, v. 324, p. 1-16, https://doi.org/10.1016/ S0040-1951(00)00111-6.

Schlagenhauf, A., Manighetti, I., Malavieille, J., and Dominguez, S., 2008, Incremental growth of normal faults: Insights from a laser-equipped analog experiment: Earth and Planetary Science Letters, v. 273, p. 299-311, https://doi.org/10.1016/ j.eps1.2008.06.042.

Soliva, R., Benedicto, A., and Maerten, L., 2006, Spacing and linkage of confined normal faults: Importance of mechanical thickness: Journal of Geophysical Research, v. 111, B01402, https:// doi.org/10.1029/2004JB003507.

Solum, J.G., and Huisman, B.A.H., 2017, Toward the creation of models to predict static and dynamic fault-seal potential in carbonates: Petroleum Geoscience, v. 23, p. 70-91, https://doi.org/10.1144/ petgeo2016-044.

Torabi, A., Ellingsen, T.S.S., Johannessen, M.U., Alaei, B., Rotevatn, A., and Chiarella, D., 2020, Fault zone architecture and its scaling laws: Where does the damage zone start and stop?, in Ogilvie, S.R., et al., eds., Integrated Fault Seal Analysis: Geological Society of London Special Publication 496, p. 99-124, https://doi .org/10.1144/SP496-2018-151.

Van Puymbroeck, N., Michel, R., Binet, R., Avouac, J.-P., and Taboury, J., 2000, Measuring earthquakes from optical satellite images: Applied Optics, v. 39, p. 3486-3494, https://doi.org/10.1364/ AO.39.003486.

Vrolijk, P.J., Urai, J.L., and Kettermann, M., 2016, Clay smear: Review of mechanisms and applications: Journal of Structural Geology, v. 86, p. 95152, https://doi.org/10.1016/j.jsg.2015.09.006.

Wibberley, C.A.J., and Shimamoto, T., 2003, Internal structure and permeability of major strikeslip fault zones: The Median Tectonic Line in Mie Prefecture, Southwest Japan: Journal of Structural Geology, v. 25, p. 59-78, https://doi .org/10.1016/S0191-8141(02)00014-7.

Wibberley, C.A.J., Yielding, G., and Di Toro, G., 2008, Recent advances in the understanding of fault zone internal structure: A review, in Wibberley, C.A.J., et al., eds., The Internal Structure of Fault Zones: Implications for Mechanical and FluidFlow Properties: Geological Society of London Special Publication 299, p. 5-33, https://doi org/10.1144/SP299.2

Wong, T.F., and Baud, P., 1999, Mechanical compaction of porous sandstone: Oil \& Gas Science and Technology: Revue d'IFP Energies Nouvelles, v. 54, p. 715-727, https://doi.org/10.2516/ ogst:1999061.

Printed in USA 